\title{
Murre foraging, epibenthic sound scattering and tidal advection over a shoal near St. George Island, Bering Sea
}

\author{
Kenneth O. Coyle', George L. Hunt, $\mathrm{Jr}^{2}$, Mary Beth Decker ${ }^{2}$, Thomas J. Weingartner ${ }^{1}$ \\ ${ }^{1}$ Institute of Marine Science, School of Fisheries and Ocean Sciences, University of Alaska Fairbanks, \\ Fairbanks, Alaska 99775-1080, USA \\ ${ }^{2}$ Department of Ecology and Evolutionary Biology, University of California, Irvine, Irvine, California 92717, USA
}

\begin{abstract}
High concentrations of 2 murre species (Uria aalge and $U$. lomvia) were observed foraging over a submarine ridge on the east side of St. George Island, Bering Sea, usually in the morning. Simultaneous measurements of tidally generated current velocity and acoustically determined biomass along transects over the ridge demonstrated that the murres were concentrating over a dense epibenthic sound-scattering layer near the ridge crest on southward ebb tide currents. Samples taken by net tows through the layer contained high numbers of euphausiids (Thysanoessa inermis and T. raschii). Stomachs of murres collected in the area contained predominantly euphausiids. When tidal currents reversed from southward to northward, the sound-scattering layer was carried northward off the ridge and the murres left the area. We hypothesize that the euphausiid aggregations resulted from the interaction of the diel downward migration of euphausiids in the morning, bottom topography and tidal currents
\end{abstract}

\section{INTRODUCTION}

Energy flow through marine ecosystems depends on a number of variables, one of which is prey concentration. While high primary production may result in favorable conditions for grazers, the efficiency of energy transfer from grazer stocks to higher trophic levels is sensitive to physical processes which influence the concentration of prey. The complex interaction of animal behavior patterns and physical processes can produce a patchy distribution of zooplankton and micronekton (Omori \& Hamner 1982, Sameoto 1983), thereby affecting feeding conditions of high level consumers.

Physical processes can transport weakly swimming or drifting organisms horizontally (Banse 1986, Scheltema 1986, Stancyk \& Feller 1986). Tidal currents and wind-induced turbulence can vertically disperse horizontal layers (Haury et al. 1990, Incze et al. 1990), or interact with bathymetry to upwell organisms to the surface (Vermeer et al. 1987, Brown \& Gaskin 1988). In addition, physical processes and behavior may interact to affect the horizontal or vertical distribution of some species (Norcross \& Shaw 1984, Epifanio 1987, Genin et al. 1988). Schneider et al. (1987) hypothesized that the interaction of flow gradients with bathymetry would result in concentrations of prey that were predictable in time and space.

Whatever the origin of zooplankton aggregations, they are an important source of energy to predators. For example, baleen whales seek out and prey on zooplankton aggregations (Kenney et al. 1986, Wishner et al. 1988) and the diets of fish are known to be influenced by prey distribution (Owen 1981, Genin et al. 1988). A variety of marine birds prey upon zooplankton aggregations associated with frontal zones (Bradstreet \& Brown 1985, Schneider et al. 1987, 1990, Hunt 1990 Hunt \& Harrison 1990), and tidal upwellings (Vermeer et al. 1987, Brown \& Gaskin 1988). Spatially and temporally predictable prey aggregations may be of particular importance to foraging birds (Schneider et al. 1987). In this paper we examine the effects of tidal currents, bathymetry and the diurnal vertical migration of euphausiids on the feeding behavior of thick- 
billed (Uria lomvia) and common (U. aalge) murres over a submarine ridge on the east side of St. George Island, Bering Sea. At this location, unusually high concentrations of murres regularly aggregate to forage on euphausiids (Hunt et al. 1981, Ford et al. 1982, Schneider et al. 1990). A frontal system associated with the 70-m isobath surrounds each of the Pribilof Islands (Kinder et al. 1983) and Schneider et al. (1990) hypothesized that a subsurface convergence-driven upwelling, similar to that described for the Irish Sea by Simpson (1981), was responsible for concentrating euphausiids, thus attracting predators. We tested this hypothesis by sampling subsurface currents and euphausiid distributions using hydroacoustic techniques.

\section{METHODS}

Information on hydroacoustic biomass, current profiles and bird distributions was collected simultaneously during daylight between 15 and 20 August 1989 over a submarine ridge to the east of St. George Island, Alaska (Fig, 1): 4 times on Transect $I 1$ and once on Transects T2, T3 and T5. On an additional 6 runs of Transect T1, we censused foraging birds, measured salinity-temperature-depth profiles of the water column at $3.7 \mathrm{~km}$ intervals, and collected plankton samples and birds for stomach analyses. Salinitytemperature-depth profiles were also taken along Transects T4 and T5 at $9.2 \mathrm{~km}$ intervals.

Hydroacoustic biomass estimates. Hydroacoustic biomass was determined using a $200 \mathrm{kHz}$ Biosonics model 101 echosounder and model 120-121 echo integrator. The transducer was mounted in a $1 \mathrm{~m} \mathrm{~V}$-fin towed beside the ship at $15 \mathrm{~km} \mathrm{~h}^{-1}, 5 \mathrm{~m}$ below the surface. The signals were blanked to $5 \mathrm{~m}$ below the

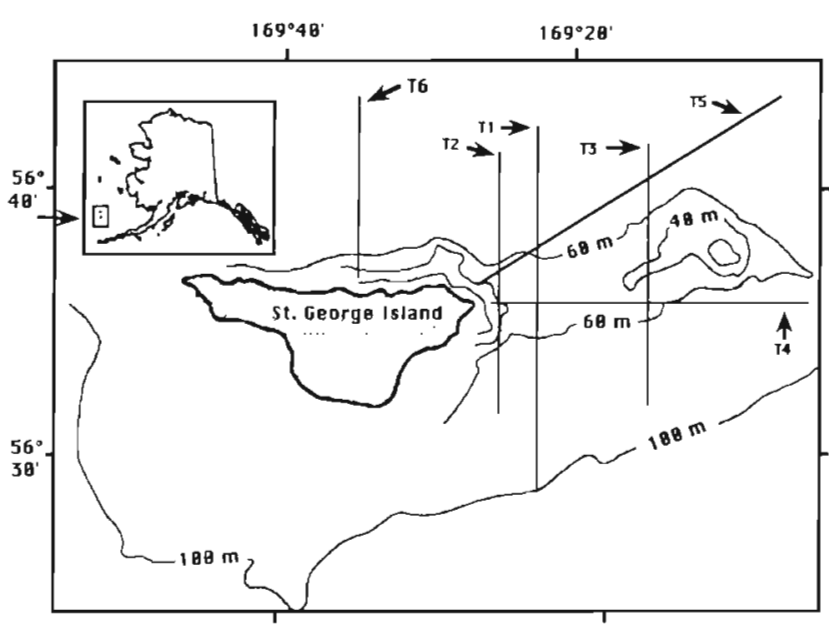

Fig. 1. Location of Transects T1 to T6 near St. George Island, Bering Sea transducer to reduce ship noise and returns from nearsurface turbulence and at 2 to $5 \mathrm{~m}$ above the bottom to avoid bottom integrations. The echo integrator resolved sound scattering intensity in 30 of $2 \mathrm{~m}$ depth intervals from 10 to $70 \mathrm{~m} ; 0.18$ to $0.36 \mathrm{~km}$ of transect were integrated for each sample along the transects. The fixed through-system gain was $-135.6 \mathrm{~dB}$, the transmitted pressure was $224 \mathrm{~dB}$, the beam pattern factor was $5.855 \times 10^{-4}$ and the assumed target strength was $-60 \mathrm{~dB}^{-1}$, which produced biomass values roughly in agreement with data from net samples. Although the use of an assumed target strength results in estimates of acoustically determined biomass $(A D B)$ in units of $\mathrm{g} \mathrm{m}^{-3}$, the data should be viewed as relative and not absolute biomass. Target strength cannot be expressed by a single value in diverse zooplankton communities (Greene et al. 1989). All contour plots were computer generated using the minimum curvature method of grid interpolation.

ADCP and CTD methods. Ocean currents were measured with a hull-mounted RD Instruments $307 \mathrm{kHz}$ Acoustic Doppler Current Profiler (ADCP) on the RV 'Alpha Helix'. Horizontal velocity data were collected in 2 min ensemble averages in $4 \mathrm{~m}$ depth bins. The data were written to an IBM-PC interfaced with the ship's LORAN-C to provide time and position for each ensemble. At typical vessel speeds of 15 to $19 \mathrm{~km} \mathrm{~h}^{-1}$, each ensemble integrated the data over a horizontal distance of 0.5 to $0.6 \mathrm{~km}$. Velocity data from depth bins shallower than $14 \mathrm{~m}$ were not used because of hullinduced contamination. Velocity data from depth bins within $15 \%$ of the bottom depth were omitted to minimize contamination associated with bottom echoes overwhelming the side-lobe suppression characteristics of the transducer. The data were edited to correct for LORAN-C errors and obviously erroneous ensembles (due to rapid acceleration of the vessel). Prior to contouring, ensembles were block-averaged ove. 6 min intervals (or about $1.5 \mathrm{~km}$ along the transect) and velocity at the surface was set equal to that at $14 \mathrm{~m}$ depth. The contour plots consist of isotachs of the east-west and n.orth-south components of velocity and the sign convention follows standard oceanographic usage: positive values indicate flow to the north or east and negative values indicate flow to the west or south.

Salinity-temperature-depth data were collected with a Neil Brown Mark III CTD.

Bird population estimates. Birds were counted from. the bridge of the ship (height of $7.7 \mathrm{~m}$ above the water) in. an arc of $300 \mathrm{~m}$ radius directly of the bow to $90^{\circ}$ off the side with the best visibility. Data were entered directly into a microcomputer. The number, species and behavior of each bird or groups of birds were recorded to the nearest $0.1 \mathrm{~min}$. Position, course, speed and observation conditions were entered every half 
hour or when significant changes occurred. The analyses of murre distributions include only those birds that were sitting on the water.

Bird stomach collection technique. Foraging thickbilled murres and black-legged kittiwakes Rissa tridactyla were collected using a 12 gauge shotgun from the bow of the ship or from a skiff. The proventriculus and ventriculus were removed promptly after collection. Each digestive tract was slit to allow entry of preservative and placed in $80 \%$ ethanol. Stomach contents were later identified to the lowest taxonomic level possible using standard keys and reference specimens. Frequency of occurrence and percent number for each prey type were tabulated. The frequency of occurrence is defined as the proportion of samples in which a given prey type occurred. Percent number is the percentage composition of prey species for all samples combined. The number of otoliths and euphausiid eyes were halved to estimate the number of fish of a given taxon or unidentifiable euphausiids in the sample. These are minimum estimates as an unknown number of eyes or otoliths may have been lost to digestion.

Zooplankton collections. Twenty-seven zooplankton samples were collected at various locations across the submarine ridge (Fig, 2) using a $1 \mathrm{~m}$ opening

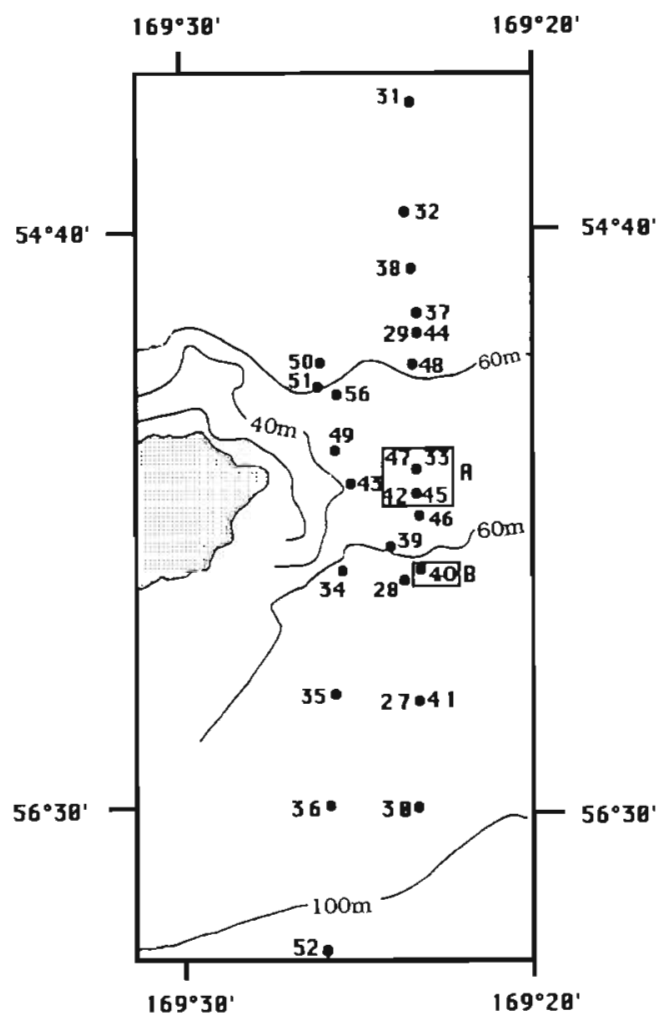

Fig. 2. Locations of midwater trawl samples over the submarine ridge on the east side of St. George Island. Boxed enclosures: approximate location of bird collections on (A) 17 and 18 August, (B) 16 August 1989
Table 1. Date, time, tow type and layer fished by trawls taken near the ridge to the east of St. George Island, 15 to 20 August 1989. Time zone was GMT+8

\begin{tabular}{|c|c|c|c|}
\hline $\begin{array}{l}\text { Trawl } \\
\text { No. }\end{array}$ & $\begin{array}{l}\text { Date } \\
\text { (Aug 1989) }\end{array}$ & Time & Tow type or layer fished \\
\hline 27 & 15 & $17: 13$ & Double oblique, 0-bottom \\
\hline 28 & 15 & $18: 18$ & Double oblique, $0-50 \mathrm{~m}$ \\
\hline 29 & 15 & $19: 06$ & Double oblique, $0-50 \mathrm{~m}$ \\
\hline 30 & 15 & $20: 04$ & Double oblique, $0-40 \mathrm{~m}$ \\
\hline 31 & 15 & $21: 04$ & Double oblique, 0 -bottom \\
\hline 32 & 16 & $10: 52$ & Weak scattering layer, $10-25 \mathrm{~m}$ \\
\hline 33 & 16 & $11: 50$ & Midwater layer, $15-25 \mathrm{~m}$ \\
\hline 34 & 16 & $12: 42$ & Double oblique, $0-50 \mathrm{~m}$ \\
\hline 35 & 16 & $13: 21$ & Double oblique, $0-50 \mathrm{~m}$ \\
\hline 36 & 16 & $14: 06$ & Double oblique, $0-75 \mathrm{~m}$ \\
\hline 37 & 16 & $17: 39$ & Double oblique, $0-65 \mathrm{~m}$ \\
\hline 38 & 16 & $17: 56$ & Weak scattering layer, $45-50 \mathrm{~m}$ \\
\hline 39 & 16 & $19: 03$ & Horizontal epibenthic, $35-40 \mathrm{~m}$ \\
\hline 40 & 16 & $19: 46$ & Diffuse layer, $15-30 \mathrm{~m}$ \\
\hline 41 & 16 & $21: 15$ & Diffuse scattering, $20-60 \mathrm{~m}$ \\
\hline 42 & 17 & $20: 43$ & Diffuse layer, $15-30 \mathrm{~m}$ \\
\hline 43 & 17 & $22: 04$ & Diffuse layer, $30-35 \mathrm{~m}$ \\
\hline 44 & 17 & $23: 15$ & Diffuse layer, $45-55 \mathrm{~m}$ \\
\hline 45 & 18 & 09:08 & Diffuse layer, $30-40 \mathrm{~m}$ \\
\hline 46 & 18 & $09: 48$ & Diffuse layer, $25-40 \mathrm{~m}$ \\
\hline 47 & 18 & $10: 53$ & $\begin{array}{l}\text { Double oblique, } 0-30 \mathrm{~m} \\
\text { weak scatter }\end{array}$ \\
\hline 48 & 18 & $12: 41$ & Dense scattering, 55-60 m \\
\hline 49 & 18 & $13: 34$ & Moderate scattering, $25-30 \mathrm{~m}$ \\
\hline 50 & 18 & $15: 15$ & Dense scattering, $50-55 \mathrm{~m}$ \\
\hline 51 & 18 & $15: 57$ & Moderate scattering, $30-35 \mathrm{~m}$ \\
\hline 52 & 18 & $20: 37$ & Diffuse scattering, $80-90 \mathrm{~m}$ \\
\hline 56 & 20 & $20: 33$ & Moderate scattering, $20-30 \mathrm{~m}$ \\
\hline
\end{tabular}

closing National Institute of Oceanography (NIO) net with $1 \mathrm{~mm}$ mesh fished at speeds of 1.8 to $3.7 \mathrm{~km} \mathrm{~h}^{-1}$ both in and outside the scattering layers (Táble 1). The net was positioned in the scattering layers using a depth recorder on the net connected with an on-deck read-out; information on the depth of the scattering layers was obtained simultaneously from a $104 \mathrm{kHz}$ echosounder. Water flow through the nets was monitored with a General Oceanics digital flowmeter. The volume and mass of large gelatinous zooplankters were estimated; the rest of the sample was preserved in $10 \%$ formalin and subsampled with a Folsom splitter to estimate population densities. Specimens were identified to the lowest taxonomic category possible, counted and measured for wet weight.

\section{RESULTS}

Tidal data and local times of sunrise and sunset for the harbor on St. Paul Island, Pribilof Islands, during the $4 \mathrm{~d}$ study are presented in Fig. 3. The number of the figure illustrating the data collected during each phase of the tide is printed below the histograms 
August 15

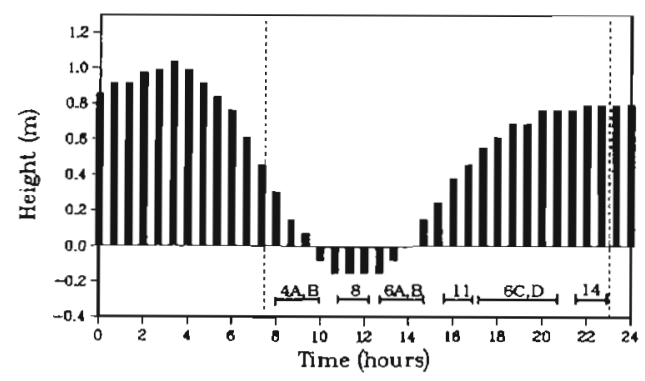

August 17

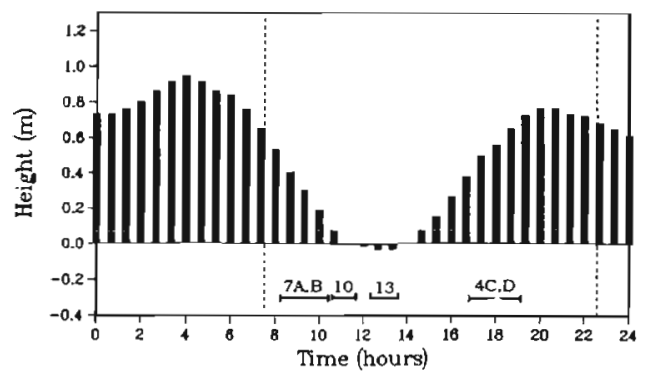

August 16

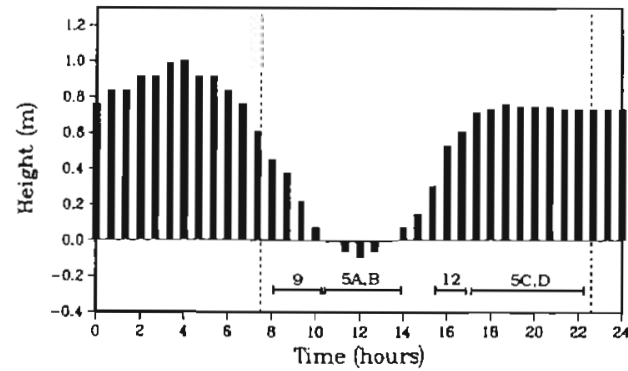

August 18

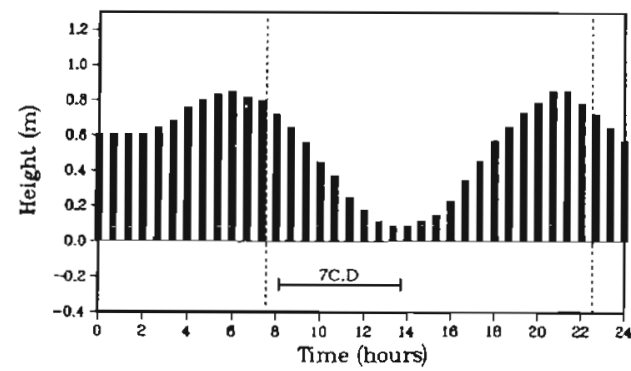

Fig. 3. Tidal cycles for 15 to 18 August 1989 at Village Cove, St. Paul Island. Plots modified from the NOAAtides program. Numbers beneath the histograms indicate the figure number illustrating ADCP, Biosonics, bird and CTD data for each transect. Dashed lines indicate sunrise and sunset illustrating tidal height. The tides were mixed with a major diurnal component. Although high tides occurred between 03:01 and 05:01 h during the study, the secondary semidiurnal component produced minor variation in sea levels during evenings and these variations appear to have altered current patterns in the study area (see below). Since the major diurnal component dominated during mornings, tides were consistently ebbing at maximum velocities following sunrise, when large feeding flocks of murres were present over the submarine ridge.

\section{Hydrography}

Two transects running out from the island were taken, one during an ebb tide (Fig. 4A, B; Transect T5) and one during a flood tide (Fig. 4C, D; Transect T4) Isohaline lines along Transect T5 bent toward the surface at about Kilometer 10 and formed a weak salinity front in the surface water at Kilometers 1 to 6 (Fig. 4B). Both salinity and temperature show a gradual transition in the epibenthic zone from about 60 to $20 \mathrm{~m}$ depth. An unstratified water column was not observed. Stratified water was observed along the entire length of Transect T4 except at the shallowest station (Fig. 4C, D). Surface temperatures varied from about 7.5 to $10^{\circ} \mathrm{C}$ over a $10 \mathrm{~km}$ distance, from about Kilometer 9 to 19 . Salinity decreased by about $0.16 \%$ from Kilometer 0 to 15. Epibenthic temperature increased from 4 to $6.5^{\circ} \mathrm{C}$ between Kilometer 12 and 0 . The actual width of the surface gradients may have been nar- rower than indicated by the plots, since the computer interpolates values between stations.

The remaining CTD transects were taken along Transect T1 (Fig. 1) at various tidal stages. The most stratified hydrographic conditions occurred during slack and flood tides (Figs. $5 \& 6$ ). The isolines were occasionally tightly bunched and bent up or down over the ridge crest (Figs. 5C, D \& 6A, B). During ebb tides, the pycnocline over the ridge was disrupted (Fig. 7). Both salinity and temperature contours were evenly spaced from surface to bottom, and bottom water salinities were lower than during other tidal phases.

\section{Currents, acoustic biomass and murre distribution}

The north-south component of horizontal velocities on the slope of the ridge occasionally changed rapidly along the transects. These north-south velocity gradients were sometimes accompanied by complementary changes in the east-west gradients, indicating directional rather than magnitudinal changes. Currents tended to be northeastward to southeastward during high-water slack, southward during ebb tide, southwestward to northwestward during low-water slack and northward during flood tide.

Transect T5 was run only once to measure current velocities, acoustic biomass and murre densities. The transect was run during late ebb tide, approaching low water slack (Figs. 3 \& 8). Currents along the whole transect were running southwestward. A single aggregate of sound-scattering organisms was located near 

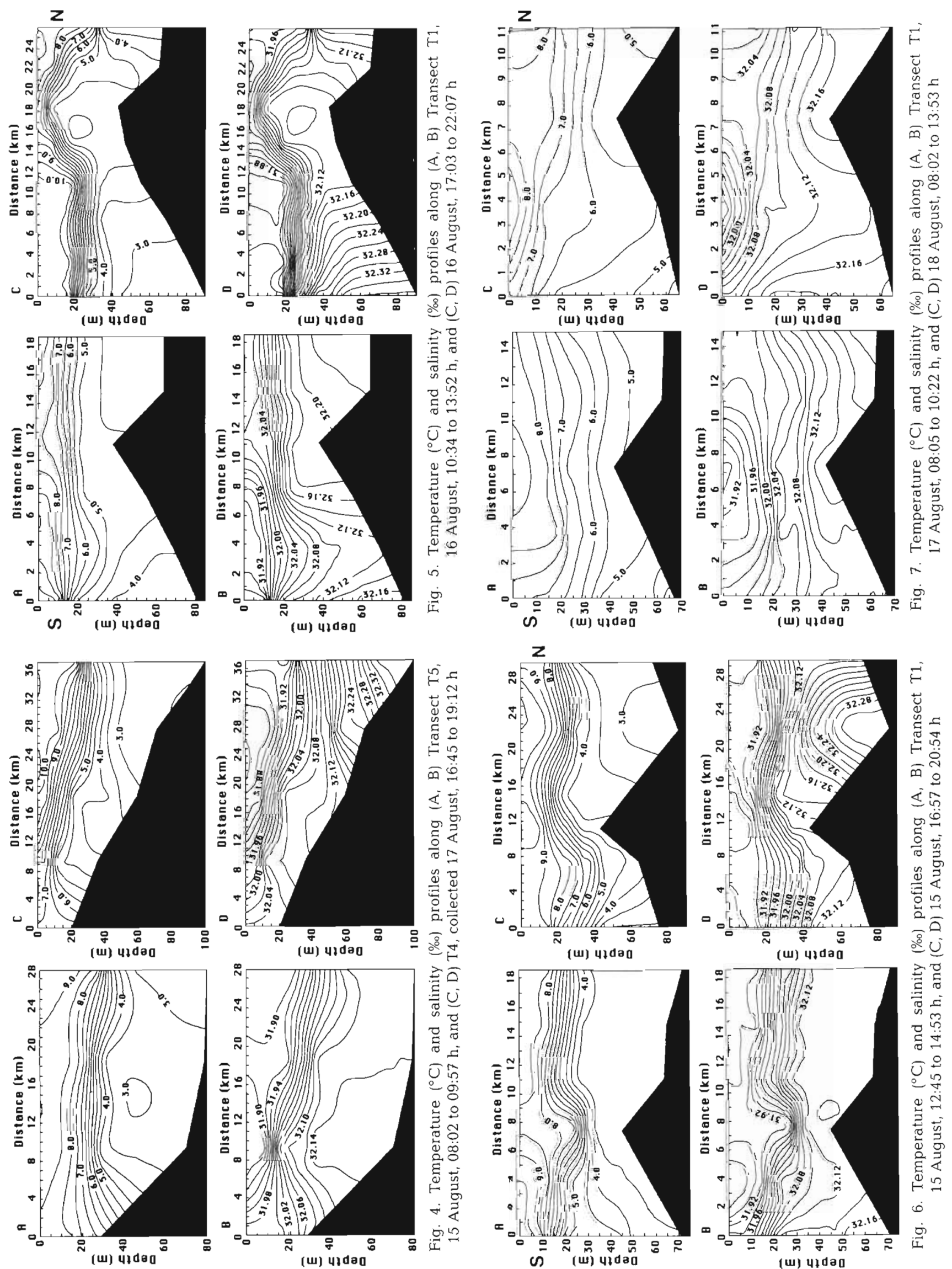

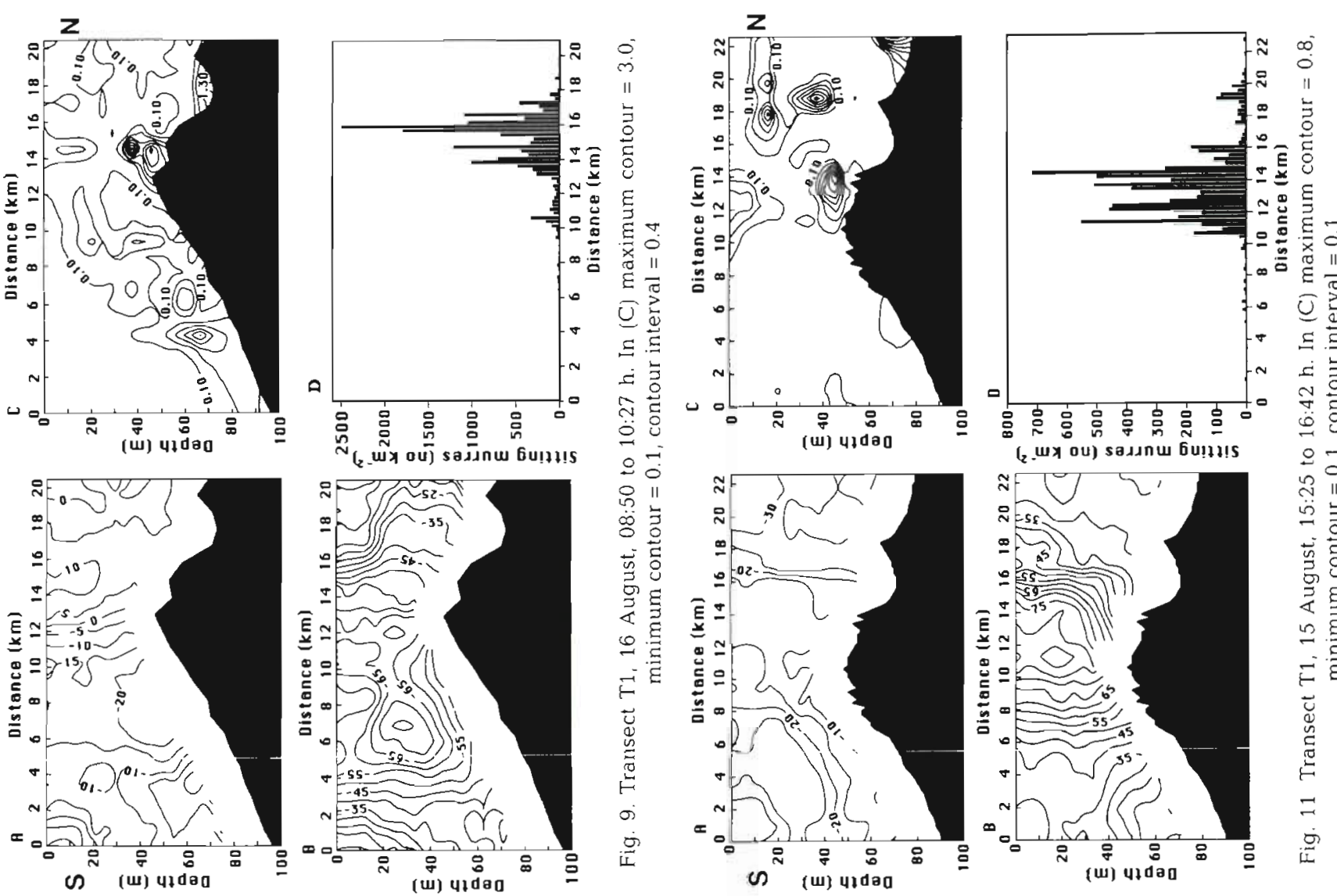

$\circ 5$

0
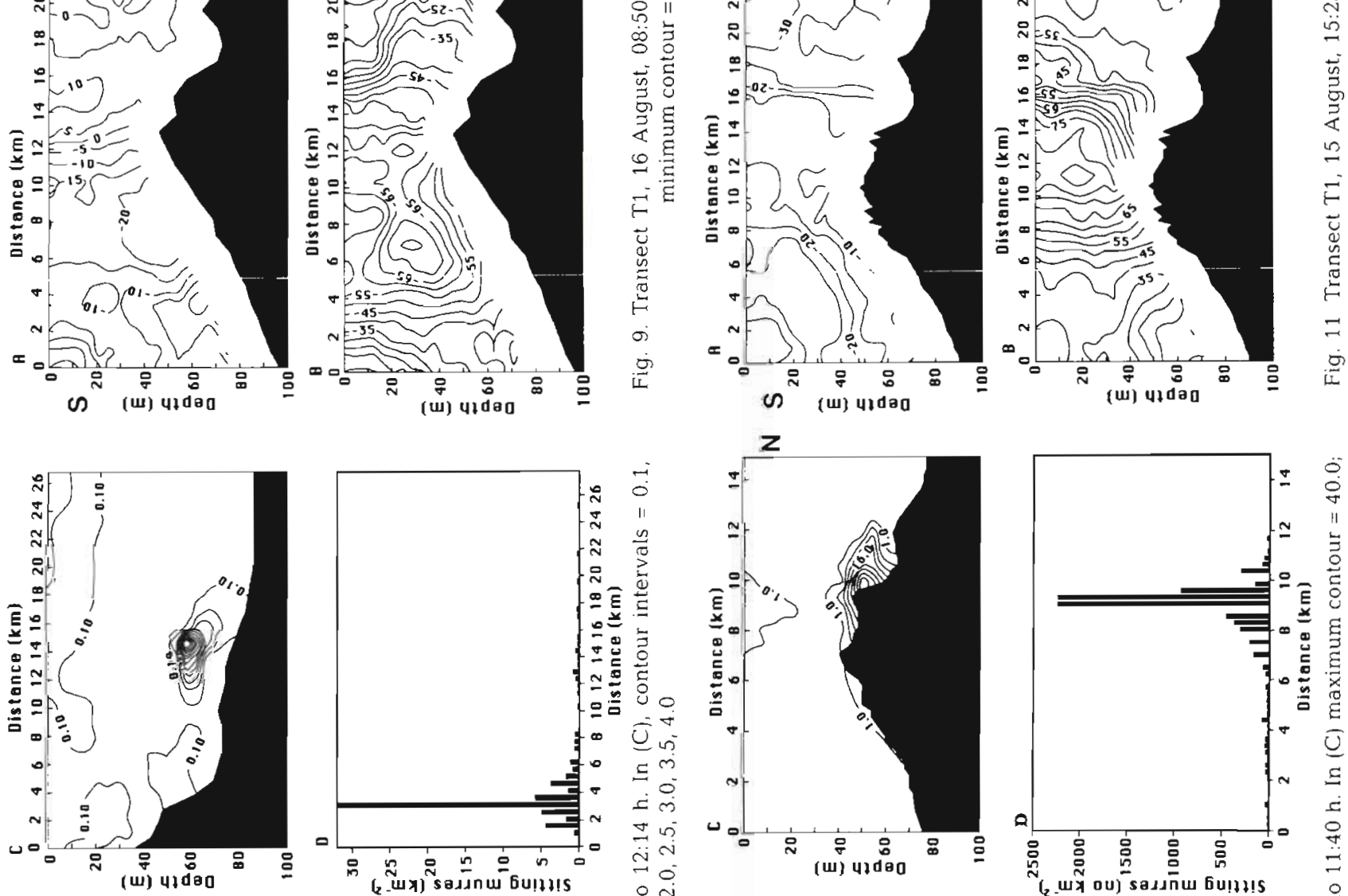

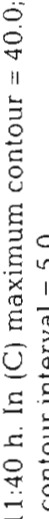
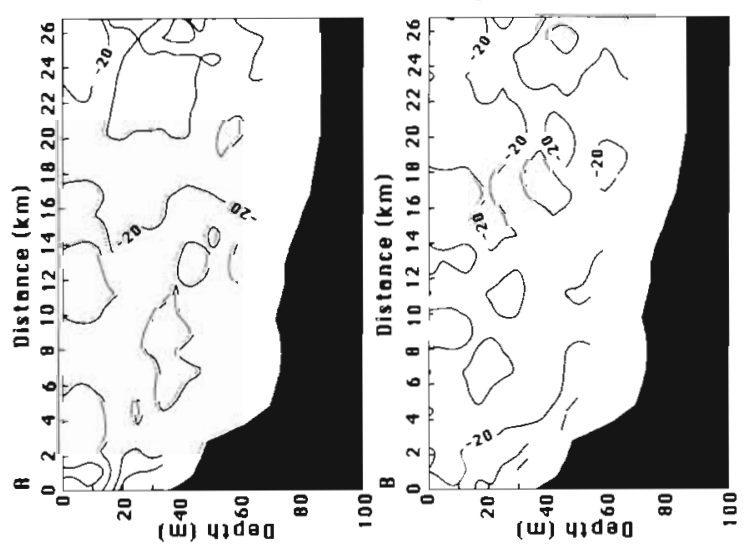

o i

5
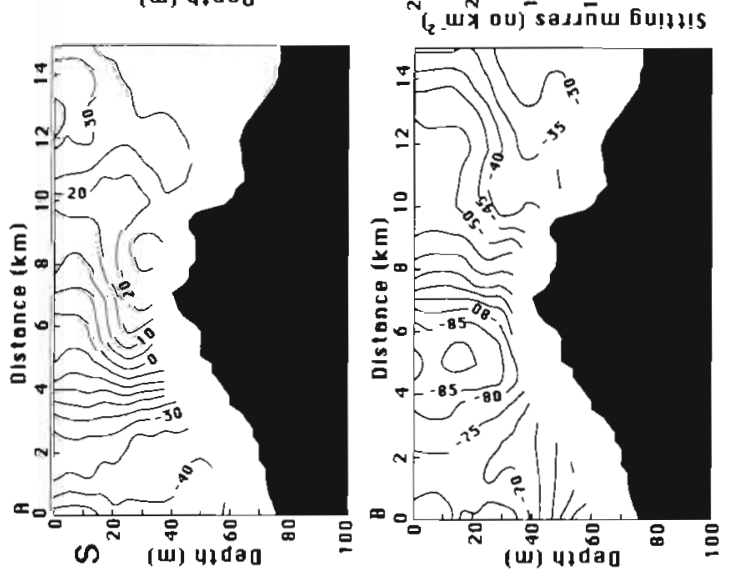

웅

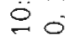

in

g.

虽

5

苞

$\rightleftarrows$

$\infty$

宁

o 

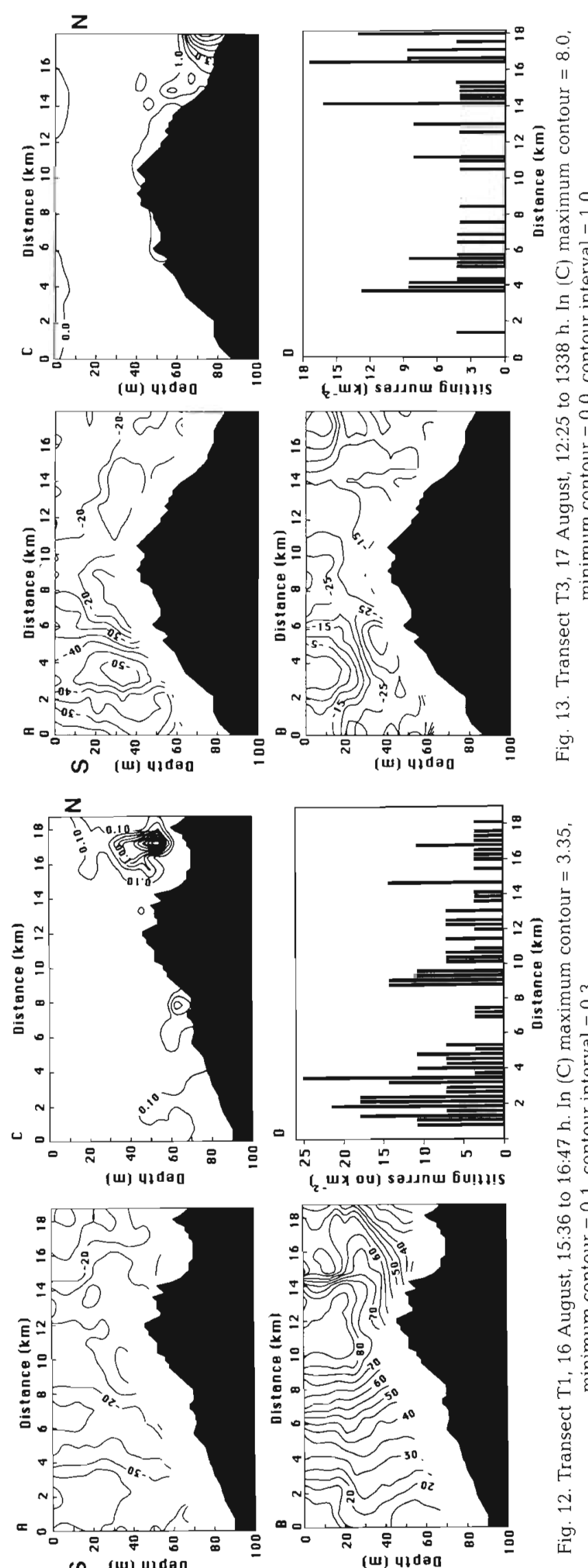
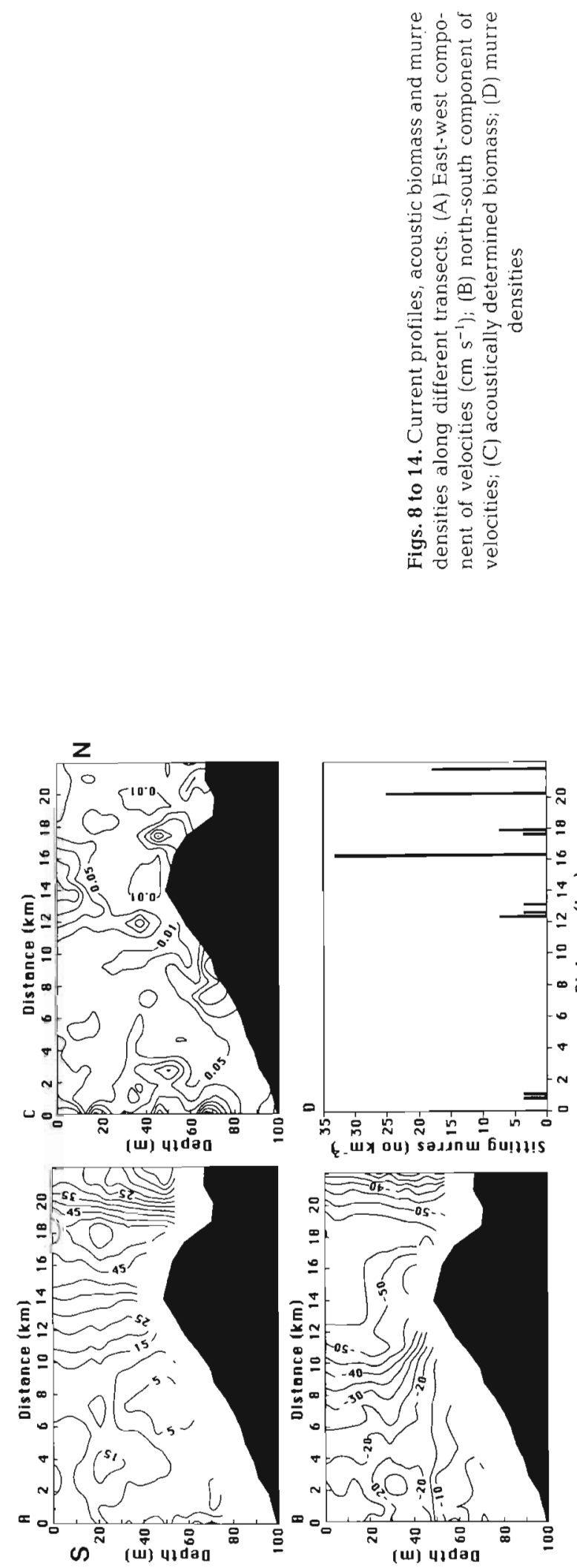

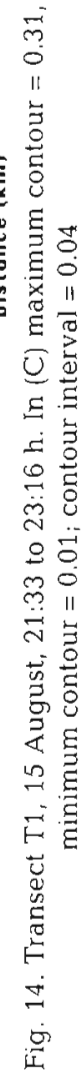

$\ddot{\mathrm{N}} \mathrm{O}$

응

लㅇ

긍

苋芯

8

를

政

$\breve{U}$

¿ $\square$ $\dot{9}$ 
Kilometer 15, at $60 \mathrm{~m}$ depth, about $10 \mathrm{~m}$ off the bottom Murre densities were minimal, with highest concentrations near the island; they were not aggregated over the scattering layer at Kilometer 15.

Two runs were made across the ridge using the ADCP and $200 \mathrm{kHz}$ echosounder in the morning during ebb tide, one along Transect T1 (Fig. 9), the other along Transect T2 (Fig. 10). The velocity data along both transects suggest that the flow veered on crossing the ridge; it was southeastward on the north side of the ridge, primarily southward at the ridge crest, and southwestward on the south side of the ridge. Maximum speeds were observed just south of the ridge crest, suggesting that this is a region of flow convergence, where southwestward flow along the south side of the ridge was augmented by southward flow across the ridge crest. Dense aggregations of sound scattering organisms were detected over the ridge crest on Transect $\mathrm{T} 1$ (Fig. 9C) and on the north side near the peak of the ridge on Transect T2 (Fig. 10C). Highest ADB values recorded in the study area (over $40 \mathrm{~g} \mathrm{~m}^{-3}$ ) occurred on Transect T2 on the north side of the ridge (Fig. 10C).
Sound scattering intensity on the south side of the ridge was substantially lower than on the north side, and distinct, intense features were absent. During both morning runs, murre concentrations of over $2000 \mathrm{~km}^{-2}$ were associated with increased back-scattering volume near the top of the ridge where water depths were 40 to $50 \mathrm{~m}$ (Figs. 9D \& 10D), well within the 153 m maximum diving depth recorded for thick-billed murres (Burger 1991). The birds appeared to be feeding. Murres collected on 17 August in the morning had predominantly fresh euphausiids in their stomachs (Table 2).

Murre densities were high over the ridge on one other run along Transect T1, when a sound scattering feature occurred at the ridge crest during flood tide, with strong northward flow over the ridge and a westward velocity component north of the ridge (Fig. 11) Although acoustic biomass estimates in the aggregations were low (contour maximum $=0.8$ ), murres were concentrated at the surface over the sound scattering feature $(40$ to $50 \mathrm{~m})$ and a secondary peak in murre densities occurred over the midwater biomass feature

Table 2. Proportion of stomach samples from thick-billed murres (TBMU) and black-legged kittiwakes (BLKI) containing a given prey $(\rho)$ and percent number of prey at St. George Ridge. Otolith numbers are presented in pairs. The proportion of samples containing a given prey can sum to more than 1.0 because a sample may contain more than one kind of prey. Present but not possible to enumerate

\begin{tabular}{|c|c|c|c|c|c|c|c|c|c|c|}
\hline & \multicolumn{2}{|c|}{$\begin{array}{c}\text { TBMU } \\
16 \text { Aug } 1989 \\
20: 30 \mathrm{~h}\end{array}$} & \multicolumn{2}{|c|}{$\begin{array}{c}\text { TBMU } \\
17 \text { Aug } 1989 \\
\text { 09:15 h }\end{array}$} & \multicolumn{2}{|c|}{$\begin{array}{c}\text { TBMU } \\
17 \mathrm{Aug} 1989 \\
19: 30 \mathrm{~h}\end{array}$} & \multicolumn{2}{|c|}{$\begin{array}{c}\text { TBMU } \\
18 \text { Aug } 1989 \\
11: 00 \mathrm{~h}\end{array}$} & \multicolumn{2}{|c|}{$\begin{array}{c}\text { BLKI } \\
18 \text { Aug } 1989 \\
11: 00 \mathrm{~h}\end{array}$} \\
\hline & $\rho$ & $\% \#$ & $\rho$ & $\%$ \# & $\rho$ & $\% \#$ & $\rho$ & $\% \#$ & $\rho$ & $\% \#$ \\
\hline Sample size & 5 & 201 & 5 & 633 & 5 & 2472 & 2 & 933 & 5 & 78 \\
\hline \multicolumn{11}{|l|}{ Euphausiacea } \\
\hline Thysanoessa inermis & 0 & 0 & 0.8 & 20.8 & 0.8 & 22.5 & 1 & 12.8 & 0.8 & 24.4 \\
\hline Thysanoessa longipes & 0.2 & 0.5 & 0 & 0 & 0 & 0 & 0 & 0 & 0 & 0 \\
\hline Thysanoessa raschii & 0.2 & 2.5 & 0.6 & 4.4 & 0.8 & 7.1 & 1 & 1.7 & 0 & 0 \\
\hline Thysanoessa spinifera & 0 & 0 & 0.2 & 0.2 & 0 & 0 & 0 & 0 & 0 & 0 \\
\hline Unid. Thysanoessa & 0 & 0 & 0.4 & 2.5 & 0.2 & 0.2 & 0 & 0 & 0 & 0 \\
\hline Unid. euphausiid & 0.2 & 6.5 & 0.8 & 70.1 & 0.8 & 68.5 & 1 & 85.0 & 1 & 61.5 \\
\hline Digested crustacean parts & 0 & 0 & 0 & 0 & 0.2 & $\cdot$ & 0 & 0 & 0 & 0 \\
\hline \multicolumn{11}{|l|}{ Fish } \\
\hline Theragra chalcogramma & 0.2 & 0.5 & 0 & 0 & 0.2 & 0.4 & 0 & 0 & 0 & 0 \\
\hline$T$ chalcogramma otolith & 0.6 & 3.5 & 0 & 0 & 0 & 0 & 0 & 0 & 0 & 0 \\
\hline Gadid otolith & 1 & 46.8 & 0.4 & 0.5 & 0.6 & 0.3 & 0.5 & 0.1 & 0.2 & 3.8 \\
\hline Ammodytes hexapterus & 0 & 0 & 0 & 0 & 0 & 0 & 0 & 0 & 0.2 & 1.3 \\
\hline Unid coltid & 0.2 & 0.5 & 0 & 0 & 0 & 0 & 0 & 0 & 0 & 0 \\
\hline Unid. Pholis otolith & 0.2 & 0.5 & 0 & 0 & 0 & 0 & 0 & 0 & 0 & 0 \\
\hline Unid. myctophid & 0 & 0 & 0 & 0 & 0 & 0 & 0 & 0 & 0.2 & 3.8 \\
\hline Unid. digested fish & 0.6 & $\cdot$ & 0 & 0 & 0.2 & $\cdot$ & 0 & 0 & 0.4 & 2.6 \\
\hline Unid. small otolith & 0.8 & 35.3 & 0.8 & 1.4 & 0.6 & 1.2 & 0.5 & 0.4 & 0.2 & 2.6 \\
\hline Unid. Copepoda & 0.4 & $\cdot$ & 0 & 0 & 0.2 & $\cdot$ & 0 & 0 & 0 & 0 \\
\hline Squild & 0.4 & 1 & 0 & 0 & 0 & 0 & 0 & 0 & 0 & 0 \\
\hline Sum & - & 100.1 & - & 99.9 & - & 99.84 & - & 100 & - & 100 \\
\hline
\end{tabular}


at 30 to $40 \mathrm{~m}$ depth, 18 to $20 \mathrm{~km}$ along the transect on the north side of the ridge (Fig. 11D). High murre densities were not observed over the ridge in the absence of an epibenthic sound scattering layer near the ridge crest (Figs. 12, $13 \& 14$ ).

One other run was made along Transect $\mathrm{T} 1$ during flood tide. At that time, a sound scattering aggregation was present at Kilometers 16 to 18 , about 2 to $3 \mathrm{~km}$ north of the ridge crest (Fig. 12C). The back scattering intensities in the aggregation at the ridge crest (Fig. 9C) and north of the ridge crest (Fig. 12C) were about equal and the transects were run on the same date; therefore, we hypothesized that the northward tidal flow had begun to transport the aggregation northward off the ridge toward deeper water. At the velocities measured (Fig. 12B), the aggregation over the ridge (Fig. 9C) could be advected 2 to $3 \mathrm{~km}$ to the position in Fig. $12 \mathrm{C}$ in ca 1.5 to $2 \mathrm{~h}$. Murres were dispersed and were not attracted to the sound scattering feature north of the ridge.

Two transects were run during slack tide, one at low-water slack and one at high-water slack. During low-water slack, the north-south velocity component along Transect $\mathrm{T} 3$ was decreasing over the ridge and a substantial westward flow had begun (Fig. 13A, B). The major biomass component was 6 to $8 \mathrm{~km}$ north of the ridge crest at 70 to $80^{\circ} \mathrm{m}$ depth (Fig. 13C). Murre densities were less than $20 \mathrm{~km}^{-2}$, with no aggregations over the scattering layer. Sound scattering intensity (Fig. 14C) was essentially at background levels during evening near high-water slack. Although the tide record

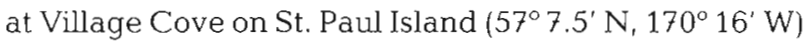
indicated high-water slack, a southward flow had begun, with a substantial eastward component on the north side of the ridge (Fig. 14A, B). The cause of the southeasterly flow is unclear, since the tide table predicted high tide at 03:55 h the following morning; however, it may have resulted from the influence of the smaller amplitude, semidiurnal tidal component.

\section{Zooplankton tows}

Two trawls, Nos. 48 and 50 (Fig. 15), were made through epibenthic scattering layers (Fig. 16) in the vicinity of dense flocks of foraging murres in the morning when ebb tide currents were running southward across the ridge. Both tows contained high numbers of euphausiids, primarily juvenile Thysanoessa inermis and low numbers of adult $T$. raschii. An additional 25 tows were made at various locations over the ridge during the day in an attempt to locate euphausiid aggregates outside the epibenthic scattering layers observed in the mornings. Horizontal tows were made through midwater scattering layers and double oblique tows were taken in regions where scattering
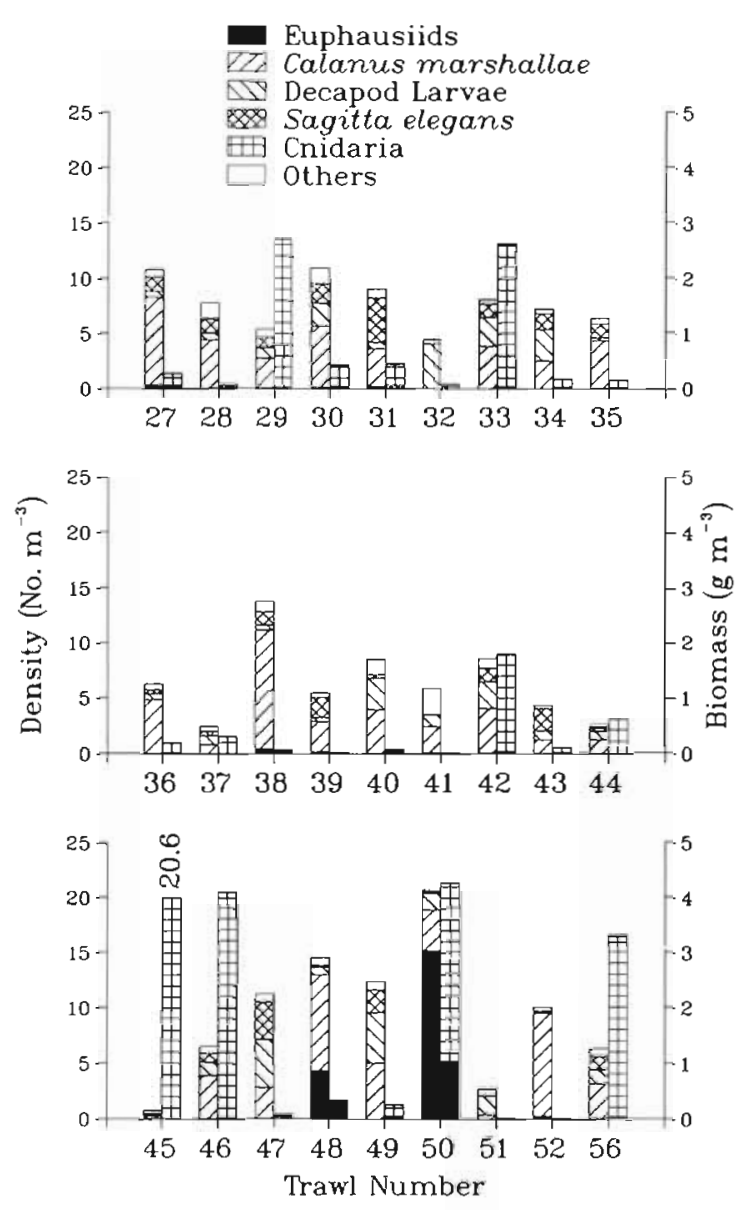

Fig. 15. Density and biomass of major taxa in the zooplankton samples taken over the shoal on the east side of St. George Island. For each trawl, left-hand bar represents density and right-hand bar represents biomass. Note: Biomass value for Trawl No. 45 was off scale; actual value is recorded above the bar

was weak and diffuse (Table 1, Fig. 2). Euphausiids in these tows were absent or present in small quantities. Zooplankton population in the midwater and oblique tows was dominated by decapod larvae (primarily pagurid and Oregoninae zoeae), Calanus marshallae and Sagitta elegans; the biomass was dominated by Cnidaria, mainly Crysara melanaster, Aequorea forskalea and Cuspidella mertensi (Fig. 15). None of the abundant taxa in midwater and oblique tows were identified from murre stomachs. However, midwater tows contained low numbers of juvenile pollock Theragra chalcogramma, a gadid commonly eaten by murres (see below).

\section{Murre foraging behavior}

On 18 August at 13:15 h we observed high numbers of murres joining a foraging flock over the St. George Island submarine ridge. Murres flew east- 

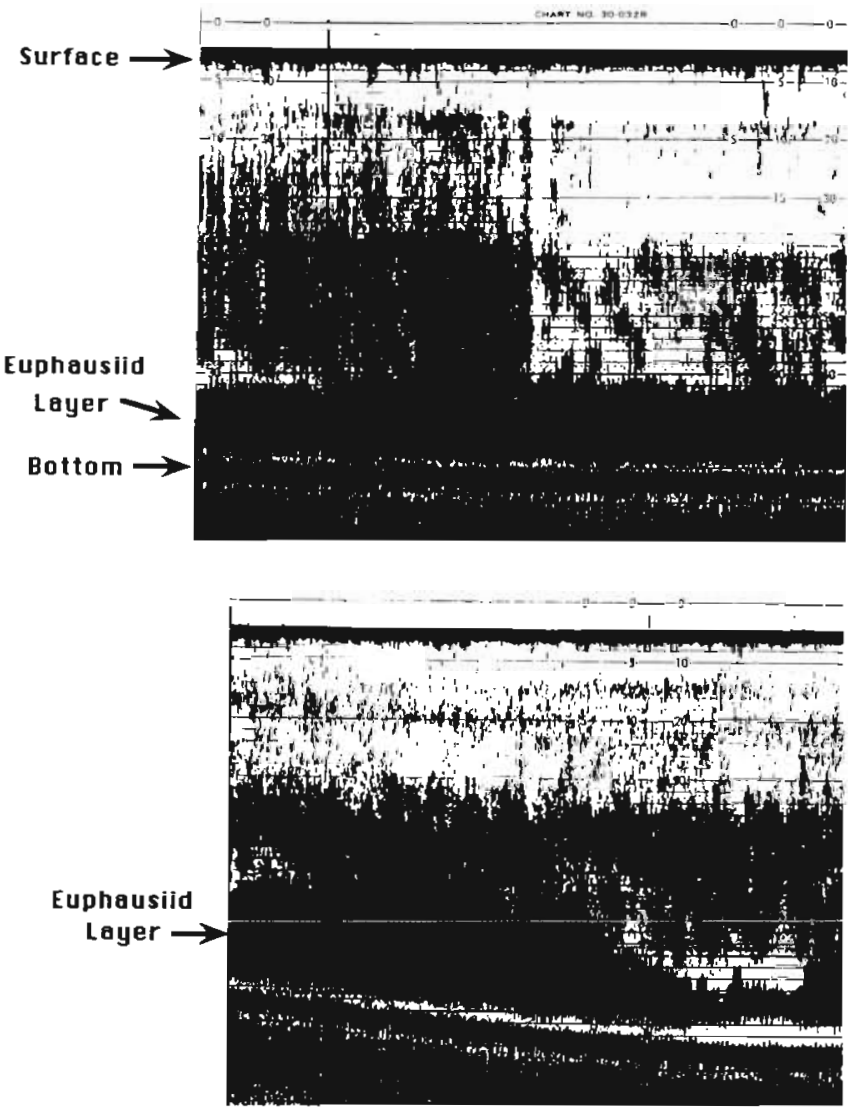

Fig. 16. Echograms showing the dense epibenthic scattering layer where Trawl Nos. 48 (upper) and 50 (lower) were taken

ward from St. George Island until they reached the vicinity of foraging flocks already on the water, and then turned northward. Incoming murres overflew the birds on the water and landed on the northern side of the foraging flock. There was a strong southward current flowing at this time $\left(50 \mathrm{~cm} \mathrm{~s}^{-1}\right.$; ADCP field data) and the foraging flock was displaced to the south by the southward flow. As the murres drifted with the current they were replaced by murres flying from the south.

When slack water occurred, northward flights by murres ceased, as did apparent foraging activity, and murres on the water began to take flight toward the southeast. After tidal currents had shifted to flow northward, we attempted to find concentrations of murres to the south of the ridge but we failed to locate any aggregations equivalent to those observed over the ridge during southward tides.

Trawl No. 46 was taken through weak scattering at 25 to $40 \mathrm{~m}$ depth (water depth was $46 \mathrm{~m}$ ), where murres were actively feeding. Euphausiid concentrations were about 66 ind. $1000 \mathrm{~m}^{-3}$ and Theragra chalcogramma were about 14 ind $1000 \mathrm{~m}^{-3}$ Scattering from bubble streams indicated that the murres were foraging at about 30 to $40 \mathrm{~m}$ depth. Thus, murres will apparently forage at fairly low prey densities, if the prey are sufficiently close to the surface.

\section{Murre stomach contents}

Murres that were collected on 16 August during highwater slack were foraging primarily on fish; the stomachs contained both small otoliths and partially digested fish (Table 2). Relatively few euphausiids were found in these samples (Table 2) and murre numbers were low (Table 3). Trawl Nos. 40 and 41 , made at the same time that the birds were collected, contained small (30 to $50 \mathrm{~mm}$ long) walleye pollock Theragra chalcogramma ( 3 ind. $1000 \mathrm{~m}^{-3}$ ), as well as the euphausiids Thysanoessa inermis and $T$. raschii (88 ind. $1000 \mathrm{~m}^{-3}$ ). Although no distinct layers were present, a $104 \mathrm{kHz}$ echogram revealed small patches of sound scattering organisms throughout the water column. Murres collected from large flocks on 1.7 August at 09:15 h, when southward currents were strong (Fig. 9), contained mainly euphausiids (Table 2). A large proportion of the murres collected later that day at 19:30 h from a relatively large flock (Table 3) had also been feeding on euphausiids (Table 2). Tows 42 to 44 (Table 1), taken through a diffuse scattering layer near the bottom shortly after the murres were collected, contained euphausiids (about 30 to 146 ind. $1000 \mathrm{~m}^{-3}$ ). On 18 August at 11:00 h during ebb tide when currents were running south, thick-billed murres and black-legged kittiwakes were feeding exclusively on euphausiids. These samples were collected shortly before trawl No. 48 , which was dominated by euphausiids (Figs. $15 \& 16$ ).

Table 3. Maximum density of murres (in birds $\mathrm{km}^{-2}$ ) calculated only over the ridge as defined by $60 \mathrm{~m}$ isobath. Time zone was GMT+8

\begin{tabular}{|cccc|}
\hline Transect & $\begin{array}{c}\text { Date } \\
\text { (Aug 1989) }\end{array}$ & $\begin{array}{c}\text { Time } \\
\text { over sill (h) }\end{array}$ & $\begin{array}{c}\text { Maximum } \\
\text { density }\end{array}$ \\
\hline T1 & 18 & $08: 31-08: 45$ & 9726.0 \\
T1 & 17 & $08: 33-09: 49$ & 4557.2 \\
T1 & 16 & $09: 40-10: 05$ & 4325.7 \\
T1 & 16 & $11: 29-12: 17$ & 1880.0 \\
T1 & 15 & $13: 30-13: 59$ & 2520.5 \\
T1 & 15 & $15: 49-16: 10$ & 1065.8 \\
T1 & 16 & $1.6: 05-16: 27$ & 24.7 \\
T1 & 15 & $18: 37-18: 54$ & 5443.0 \\
T1 & 16 & $18: 38-19: 32$ & 60.5 \\
T1 & 18 & $19: 06-19: 29$ & 232.4 \\
T1 & 15 & $22: 08-22: 28$ & 22.8 \\
T2 & 17 & $11: 01-11: 22$ & 3822.6 \\
T3 & 17 & $12: 41-13: 16$ & 11.2 \\
& & & \\
\hline
\end{tabular}




\section{DISCUSSION}

Highest densities of foraging murres on the ridge were consistently located at the surface over epibenthic scattering layers near the ridge crest. Although epibenthic scattering layers were also occasionally present to the north of the ridge crest, they were not associated with high murre densities. In the absence of an epibenthic scattering layer on the ridge crest, murre densities were reduced by at least 2 orders of magnitude. Stomach content analyses of murres foraging over the ridge demonstrated that they were eating primarily euphausiids, and zooplankton tows through the epibenthic scattering layers indicated that at least a portion of the layers consisted of euphausiids. The murres were therefore apparently attracted to prey organisms in scattering layers if the scattering layers were at the ridge crest.

The sound scattering aggregates at the ridge crests could be concentrated and dispersed by conditions on the ridge, or formed elsewhere and transported to the ridge by tidal currents. Assuming an ebb tide duration of $6 \mathrm{~h}$ (Fig. 3) and average flow velocities of about $40 \mathrm{~cm} \mathrm{~s}^{-1}$, processes forming the aggregates would have to be operating within about $8 \mathrm{~km}$ of the ridge crest. At greater distances, transport processes could not move the organisms onto the ridge crest in a single tidal cycle.

Euphausiids may have been concentrated on the ridge by a combination of their diurnal vertical migration behavior and tidal advection. During morning, the downward migration of euphausiids through a vertical velocity gradient associated with baroclinic tidal advection would have concentrated the organisms in the epibenthic layer where flow rates are minimal. Those on the south side of the ridge would have been swept southward toward deeper water and migrated downward away from the study site. If epibenthic flow rates were less than about $5 \mathrm{~cm} \mathrm{~s}^{-1}$, the maximum estimated swimming speed of euphausiids (Simard \& Mackas 1989), the scattering layers on the north side of the ridge could have remained in place. If epibenthic velocities exceeded euphausiid swimming speeds, the scattering layer would have been swept toward the ridge crest, where predation by murres could occur. Vertical shear is probably greatest in the bottom $5 \mathrm{~m}$, where speeds decrease to about half their mid-water and surface values (Maas \& van Haren 1987). Current velocities within the bottom layer on the ridge are probably sufficient to advect the epibenthic scattering layers (Figs. 9C \& 10C) northward or southward over the ridge during flood and ebb tides, respectively.

Schneider et al. (1990), who studied murre foraging near Trawl Stn 48 (Fig. 2), postulated that a subsurface convergence zone, beneath a surface divergence, con- centrated euphausiids. Such subsurface convergences are theoretically produced near tidally generated frontal regions, identified by the presence of intense horizontal property gradients in the surface layer (Simpson 1981). Tidally generated fronts essentially divide stratified and unstratified, mixed water. Water column structure was stratified along both Transects $T 4$ and T5 (Fig. 4). Horizontal property gradients in the surface water were weak and a uniformly mixed water column was not observed. Although we found no evidence of a tidally generated front near Trawl Stn 48 during August 1989 a distinct epibenthic sound scattering layer was observed, but murres were not attracted to it (Fig. 8C, D).

While tidally generated, subsurface convergences were not detected on the ridge during our study, such convergences may have been generated along the north shore of the island (Transect T6; Fig. 17). The subsurface density maximum on the mixed side of the front and the upward projection of the isopycnals (Fig. 17C; Kilometer 7 to 10) are indications of a subsurface convergence and upwelling in frontal regions (Simpson 1981). Such conditions might concentrate organisms in the convergence zone shoreward of the front. Alternatively, euphausiids migrating downward might simply collect at the base of the escarpment on the north side of the island, especially if the southward component of the epibenthic currents prevented them from being swept northward across the shelf and away from the island (Fig. 17B). Any organisms concentrated in the epibenthic zone near the island would be advected southeastward along the base of escarpment and onto the north side of the ridge during ebb tide (Fig. 17A). The above mechanisms may have produced the intense scattering observed on the north side of the ridge along Transect T2 (Fig. 10C)

The above mechanism would also account for differences in water column structure over the ridge between ebb and flood tides. The weak vertical stratification during ebb tide (Fig. 7) might be produced by turbulence on the north side of the island shoreward of the front. The mixed water would then be swept southeastward along the north side of the island and onto the ridge, as suggested by the similarity in salinity-temperature signatures of the water column over the ridge (Fig. 7) and near the $40 \mathrm{~m}$ isobath on Transect T5 (Fig. 4A, B) during ebb tide. The more stratified conditions during flood tide probably resulted from northwesterly flow, moving stratified water up onto the ridge. The higher bottom water salinities on the slope of the ridge following flood tide (Figs. 5D $\& 6 D$ ) suggest that deep water had been pushed onto the ridge by the northward flow.

Water column stratification can markedly influence the vertical distribution of sound scattering organisms. 

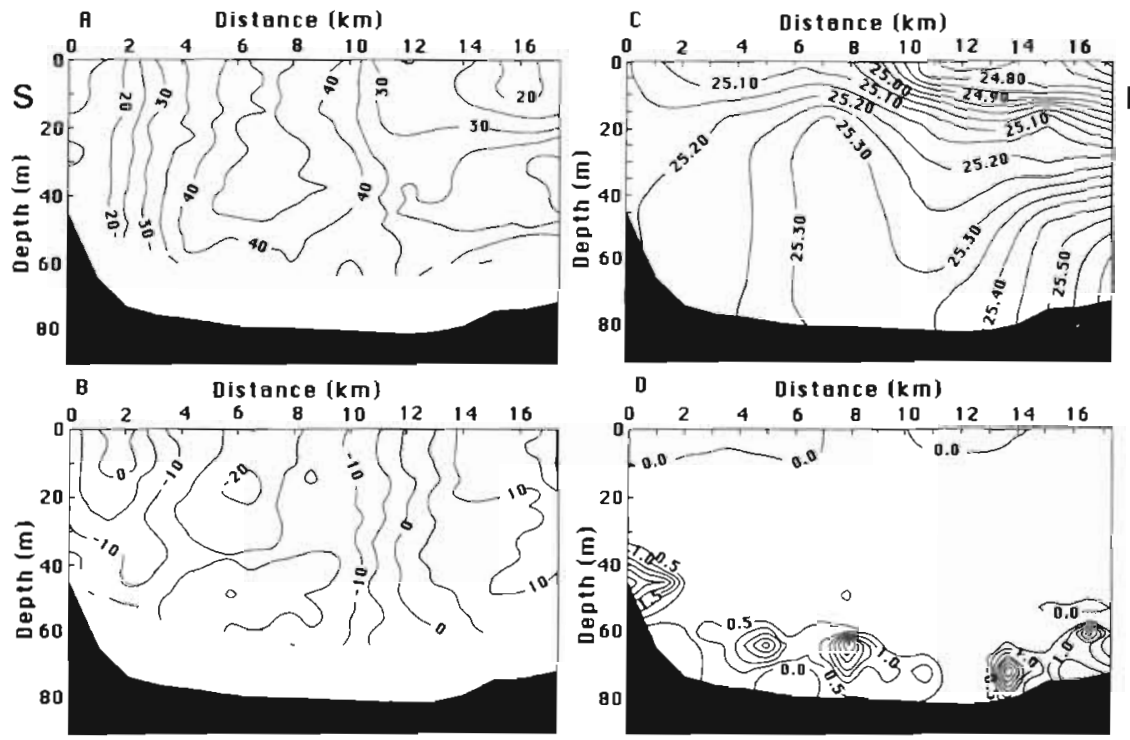

$N$

Fig. 17. Current profiles, water column density profile and acoustic biomass collected along Transect $T \hat{6}$, north of St. George Island. (A) East-west component of velocities $\left(\mathrm{cm} \mathrm{s}^{-1}\right)_{i}$ (B) northsouth component of velocities; (C) water density (sigma-t units); (D) acoustically determined biomass (contour maximum $=3.5$, contour minimum $=0.0$ i contour interval $=0.5$ ). Density data collected 23 August, $08: 05$ to $12: 02 h_{\text {; }}$ current profiles and acoustic biomass collected 23 August, $13: 19$ to $14: 29 \mathrm{~h}$

Sound scattering was occasionally most intense in and above the thermocline on the stratified side of tidally generated fronts, particularly arnund St Paul Island (Coyle \& Cooney in press). Intense pycnoclines with no detectable sound scattering were also found away from frontal regions. Sound scattering in the pycnoclines is therefore apparently due to higher densities of sound scattering organisms near the pycnocline rather than reflection of sound waves by the pycnocline. In addition, murres near St. George Island were foraging when epibenthic scattering layers were present below the thermocline during ebb tides, when pycnoclines were weakest. Murres were basically absent from the ridge crest during flood tides when pycnoclines were strongest. Thus, although some scattering from pycnoclines may have occurred, it did not attract foraging murres.

While highest epibenthic sound scattering intensities and densities of foraging murres occurred in the mornings during ebb tides, an epibenthic scattering layer and associated flock of foraging murres occurred in the evening, during flood tide, on 15 August (Fig. 11D, Table 3). Thus, prey organisms can be swept onto the ridge crest by flood tides as well as ebb tides. Since water depth on the north side of the ridge is shallower than on the south side, epibenthic aggregates swept northward by tidal exchange will be closer to the surface and more likely to be swept southward, back across the ridge crest by the succeeding tidal phase.

Both bird feeding observations and acoustic biomass data indicate the dynamic nature of the processes transporting and concentrating prey organisms. Over periods of 1 or $2 \mathrm{~h}$, often during slack tides, dense foraging flocks dispersed and prey aggregates disappeared from the ridge crest. While foraging flocks may remain on the ridge crest for extended periods, the duration of feeding is probably a function of the number of succeeding prey aggregates advected onto the ridge. Given the current velocities measured during flood and ebb tides, it is unlikely that single aggregates could have maintained a fixed position at the ridge crest.

The epibenthic layer was specifically targeted for sampling twice, both times during ebb tide on the north side of the ridge. Both catches were numerically dominated by euphausiids. The remaining tows were oblique tows or midwater tows through scattering layers above the thermocline (Table 1). Although the number of samples through epibenthic scattering layers on the ridge were minimal, similar layers sampled elsewhere around the Pribilof Islands contained euphausiids (Coyle \& Cooney in press). In addition, the epibenthic scattering layers were often detected by a $200 \mathrm{kHz}$ system but transparent to a $38 \mathrm{kHz}$ system (Coyle \& Cooney in press). Thus, the layers during the day were probably not dominated by large gelatinous zooplankton or fish. Furthermore, the layers migrated to the surface at night, night tows contained high numbers of euphausiids (Coyle \& Cooney in press), and murres foraging in the layers during the day were taking predominantly euphausiids. Therefore, if the epibenthic sound scattering was not caused by euphausiids, it was the result of organisms consistently associated with them.

Sound scattering from euphausiid aggregations is not unique to the Pribilof Islands. Hydroacoustic data have revealed dense layers of euphausiids in a variety of coastal habitats (Pieper 1979, Macaulay et al. 1984, Simard et al. 1986, Greene et al. 1988, 1989, Simard \& Mackas 1989). When swept over shallow regions, 
euphausiid aggregations can be trapped against the bottom as they attempt to migrate to deep water in the morning, and thus become available to and exploited by fish (Genin et al. 1988, Simard \& Mackas 1989), as well as birds and whales

Euphausiids can also be actively upwelled to the surface by strong tidal currents flowing against topographic obstructions and thus become accessible to surface-feeding birds such as phalaropes (Phalaropus spp.) (Brown \& Gaskin 1988) or Bonaparte's (Larus philadelphia) and mew gulls (L. canus) (Vermeer et al. 1987). In the present study, the capture of euphausiids by surface-foraging black-legged kittiwakes was most likely due to the injury of euphausiids at depth by foraging murres, a mechanism similar to that hypothesized by Schneider et al. (1990) for this region and documented at St. Matthew Island by Hunt et al. (1988). We saw no indications that euphausiids were being actively upwelled to the surface in the study region.

We observed an average density of 6179 murres $\mathrm{km}^{-2}$ over the ridge crest $\left(4.6 \mathrm{~km}^{2}\right)$ during a given peak in foraging. This density is ca $50 \%$ higher than that reported by Hunt (1977), who found 3886 murres $\mathrm{km}^{-2}$ in an area of $101 \mathrm{~km}^{2}$ for the same geographical region. High numbers of murres have also been reported foraging on euphausiids to the east of St. Matthew Island (Hunt et al. 1988). At each island, the total number of murres foraging on euphausiids represented a substantial portion of the resident murre population. Thus, these sites are important sources of energy for the nearby breeding colonies.

Despite similar concentrations of foraging murres and types of prey taken at both St. Matthew and St. George Islands, the physical mechanisms responsible for the 2 phenomena appear to be different. At St. George Island, tidal currents impinge on a submarine ridge. In contrast, Hunt et al. (1988) hypothesized that tidally generated eddies in the island's wake were responsible for concentrating prey at St. Matthew Island Behavioral observations of the murres support the hypothesized differences in physical mechanisms. At St. Matthew Island, murres foraged in small- to medium-sized flocks, each of which moved independently of the others. All birds within each flock, however, moved together as a unit and appeared to track aggregations of prey below the surface. At St. George Island, a single large aggregation of murres contained individuals that were all on the surface oriented to the north, into the tidal current. These studies provide examples of interactions between biological and physical processes in marine systems that create patches which can be efficiently exploited by marine animals. Locations where these aggregations occur predictably are important foraging sites (Schneider et al. 1987 1990, Brown \& Gaskin 1988), especially for those higher level consumers having elevated metabolic demands, particularly during breeding season.

Acknowledgements. We thank L. Baretta, E. Flint, A. John, B. Leventhal, M. Miller, K. Ryder and L. Wilson for help with field work. The captain, crew and marine technician of the RV 'Alpha Helix' provided superb support. R. Russell, E. Woehler. D. Schneider and the anonymous referees gave useful suggestions for improving the manuscript. The research was supported in part by the Institute of Marine Science, University of Alaska Fairbanks, and by the National Science Foundation, Grant DPP8521178 to G. Hunt. This is Contribution No, 898 from the Institute of Marine Science, University of Alaska Fairbanks.

\section{LITERATURE CITED}

Banse, K. (1986). Vertical distribution and horizontal transport of planktonic larvae of echinoderms and benthic polychaetes in an open coastal sea. Bull. mar. Sci. 39(2): 162-175

Bradstreet, M. S. W., Brown, R. G. B. (1985). Feeding ecology of the Atlantic Alcidae. In: Nettleship, D. N., Birkhead, T. R. (eds.) The Atlantic Alcidae. Academic Press, New York, p. $263-318$

Brown, R. G., Gaskin, D. E. (1988). The pelagic ecology of the grey and red-necked phalaropes Phalaropus fulicarius and $P$. lobatus in the Bay of Fundy, Canada. Ibis 130: $234-250$

Burger, A. D. (1991). Maximum diving depths and underwater foraging in alcids and penguins. In: Montevecchi, W. A., Gaston, A. J. (eds.) Studies of high-latitude seabirds. 1. Behavioral, energetic, and oceanographic aspect of seabird feeding ecology. Canadian Wildlife Service Occasional Paper No. 68, Ottawa, p. 9-15

Coyle, K. O., Cooney, R. T. (in press). Water column sound scattering and hydrography around the Pribilof lslands, Bering Sea. Cont. Shelf Res.

Epifanio, C. E. (1987). The role of tidal fronts in maintaining patches of brachyuran zoeae in estuarine waters. J. Crust. Biol. 7: 513-517

Ford, G. R., Weins, J. A., Heinmann, D., Hunt, G. L. (1982) Modeling the sensitivity of colonially breeding marine birds to oil spills: Guillemot and Kittiwake populations on the Pribilof Islands, Bering Sea. J appl. Ecol. 19: 1-31

Genin, A., Haury, L., Greenblatt, P. (1988). Interactions of migrating zooplankton with shallow topography: predation by rockfishes and intensification of patchiness. Deep Sea Res. 35: 151-175

Greene, C. H., Wiebe, P. H., Burczynski, J., (1989). Analyzing zooplankton size distribution using high-frequency sound. Limnol. Oceanogr. 34(1): 163-178

Greene, C. H., Wiebe, P. H., Burczynski, J., Youngbloth, M. J. (1988). Acoustic detection of high density demersal krill layers in the submarine canyons off Georges Bank. Science 241: 359-361

Haury, L. R., Yamazaki, H., Itsweire, E. C. (1990). The effect of turbulent flow on zooplankton distribution. Deep Sea Res. 37: $447-461$

Hunt, G. L., Jr (1977). Reproductive ecology, foods, and foraging areas of seabirds nesting on the Pribilof Islands. Environmental Assessment of the Alaskan Continental Shelf: Annual Reports of Principal Investigators for the Year Ending March 1977. Vol. 2. Outer Continental Shelf Environmental Assessment Program, Boulder, p. 196-382 
Hunt, G. L., Jr (1990). The pelagic distribution of marine birds in a heterogeneous environment. Polar Res. 8: $43-54$

Hunt, G. L., Jr, Eppley, Z., Burgeson, B., Squibb, R. (1981). Reproductive ecology, foods and foraging areas of seabirds nesting on the Pribilof Islands, 1975-1979. Environmental assessment of the Alaskan continental shelf; final reports of principle investigators, Vol. 12. NOAA/OMPA. Washingtor, D.C., p. 1-257

Hunt, G. L., Jr, Harrison, N. M. (1990). Foraging habitat and prey selection by Least Auklets at King Island, Alaska. Mar. Ecol. Prog. Ser. 65: 141-150

Hunt, G. L., Jr, Harrison, N. M., Hamner, W. M., Obst, B. S. (1988). Observations of a mixed-species flock of birds foraging on euphausiids near St. Matthew Island, Bering Sea. Auk 105: 345-349

Incze, L. S., Ortner, P. B., Schumacher, J. D. (1990). Microzooplankton, vertical mixing and advection in a larval fish patch. J. Plankton Res. 12: 365-379

Kenney, R. D., Hyman, M. A., Owen, R. E., Scott, G. P., Winn, H. E. (1986). Estimation of prey densities required by western North Atlantic right whales. Mar. Mammal Sci. 2: $1-13$

Kinder, T. H., Hunt, G. L., Schneider, D. C., Schumacher, J. D. (1983). Correlation between seabirds and oceanic fronts around the Pribilof Islands, Alaska. Estuar. coast. Shelf Sci. 16: 309-319

Maas, L. R. M. Van Haren, I. I. M. (1987). Observations on the vertical structure of tidal and inertial currents in the central North Sea. J. mar. Res. 45: 293-318

Macauley, M. C., English, T S., Mathisen, D. A. (1984). Acoustic characterization of swarms of Antarctic krill (Euphausia superba) from Elephant Island and Bransfield Strait. J. Crust. Bjol. 4: 16-44

Norcross, B. L., Shaw, R. F. (1984). Oceanic and estuarine transport of fish eggs and larvae: a review. Trans. Am. Fish. Soc. 113: 153-165

Omori, M., Hamner, W. M. (1982). Patchy distribution of zooplankton: behavior, population assessment and sampling problems. Mar. Biol. 72: 193-200

This article was presented by D. C. Schneider, La Jolla, California, USA
Owen, R. W. (1981). Fronts and eddies in the sea: mechanisms, interactions and biological effects. In: Longhurst, A. R. (ed.) Analysis of marine ecosystems. Academic Press, London, p. 197-233

Pieper, R. E. (1979). Euphausid distribution and biomass determined acoustically at $102 \mathrm{kHz}$. Deep Sea Res. 26: $687-702$

Sameoto, D. D. (1983). Euphausid distribution in acoustic scattering layers and its significance to surface swarms. J. Plankton Res. 5: 129-143

Scheltema, R. S. (1986). On dispersal and planktonic larvae of benthic invertebrates: an eclectic overview and summary of problems. Bull. mar. Sci. 39: 290-322

Schneider, D. C., Harrison, N. M., Hunt, G. L. Jr (1987). Variation in the occurrence of marine birds at fronts in the Bering Sea. Estuar. coast. Shelf Sci. 25: 135-141

Schneider, D. C., Harrison, N. M., Hunt, G. L. Jr (1990). Seabird diet at a front near the Pribilof lslands, Alaska. Stud. avian Biol. 14: 61-66

Simard, Y., Mackas, D. L. (1989). Mesoscale aggregation of euphausiid sound scattering layers on the continental shelf of Vancouver Island. Can. J. Fish. Aquat. Sci. 46: $1238 \cdot \cdot 1249$

Simard, Y., de Ladurantaye, R., Therriault, J. (1986). Aggregation of euphausiids along a coastal shelt in an upwelling environment. Mar. Ecol. Prog. Ser. 32: 203-215

Simpson, J. H. (1981). The shelf-sea front: implications of their existence and behavior. Phil. Trans. R. Sor. Lond. 4.302 $531-546$

Stancyk, S. E., Feller, R. J. (1986). Transport of non-decapod invertebrate larvae in estuaries: an overview. Bull. mar. Sci. 39: $257-268$

Vermeer, K., Szabo, I., Greisman, P. (1987). The relationship between plankton-feeding Bonaparte's and Mew gulls and tidal upwelling at Active Pass, British Columbia. J. Plankton Res. 9: 438-501

Wishner, K., Durbin, E., Durbin, A., Macauley, M., Winn, H., Kenney, R. (1988). Copepod patches and right whales in the Great South Channel off New England. Bull. mar. Sci. 43: $825-844$

Manuscript first received: June 2, 1991

Revised version accepted: April 28, 1992 